\title{
New Era of Muslim Women in Malay World: The Contested Women's Advancement in Decision Making Bodies
}

\author{
Erni Haryanti ${ }^{1}$ \\ 1Tarbiya and Education Faculty at UIN Sunan Gunung Djati Bandung \\ E-Mail: erniharyanti@hotmail.com
}

\begin{abstract}
Malay world has been experiencing the conflicting and converging international influences of globalization and rapid Islamisation in many significant aspects of the countries. One of the issues is that the impact of the agenda of advancement of women's life to achieve gender equality promoted by international agencies. Among other women's improvement agenda is that woman in decision making bodies. On the other hand, the growing visible Islamic movement (and/or Islamic fundamentalism - Islamism) which may significantly grow among Malay societies would unavoidably create different ideas, attitudes and practices compared to other Muslim world. This paper explores myriad aspects of women's empowerment transforming into decision making bodies in the nuances of an affirmative action a recommendation of series of international conference on women. Through finding similarities and differences between the two Muslim majority countries, the support toward Muslim women's empowerment in decision making bodies is formally acknowledged in state regulations. Although women of Southeast Asian region are culturally recognized to have a high status and well engagement with public sphere, in the implementation of women representing themselves in political sphere has a little difference. In term of discourses Indonesia has much flourished ideas and closer to the ideas of international agenda than that of Malaysia. In the overall Malay world would gradually show its openness, tolerance and positive adaptation as a part of world society, although it cannot avoidably be departed from international agenda of both carrying Islamic and non-Islamic values.
\end{abstract}

Keywords: Muslim women in South-east Asia, women in decision making, Affirmative Action

\section{A. INTRODUCTION}

Southeast Asia is located at a very strategic region for most nations that span between the Indian and Pacific Oceans and range between Asia and Australia. It is no wonder if South-east Asia is susceptibly affected by many global influences. It is resided by multi-racial and multi-religious people, but is inherently recognized as peaceful, harmonious and tolerant characters. Recently, it has been witnessed the emergence of the so-called Islamic fundamentalism. At the same time, movement of achieving gender equality promoted by the United Nations (UN) also becomes apparent in the region. Indonesia and Malaysia are among the South-east Asia countries occupied by Muslims, as majority would inevitably have been shaped by these two different global influences, although different characteristics may emerge apart from similarities.

As neighbors, these two countries should inevitably have similarities characterized by race and religion, besides other aspects such as social, economical, political and cultural characters. In reality, due to globalizing influences and openness attitudes have been experienced within the two countries since the last two decades there should have been differences of such various dynamic changes resulted in either positive or negative impacts. A study done by Greg Fealy, for example, shows that Indonesia and Malaysia's policies towards Islamic fundamentalism - Islamism - have a 
little difference (Greg Fealy in Nelly Lahoud and Anthony H. Johns, 2005). This kind of attitude would have been similar to the case of gender equality, such mentioned in the study of Claudia Derichs and Andrea Fleschenberg (Claudia Derichs and Andrea Fleschenberg, 2010). Thus, this paper would like to explore the similarities and differences of Indonesia and Malaysia in confronting and diverging global values in the idea of gender equality with a special reference of women in decision making bodies through the lens of the fact that these are the most populous Muslim countries. In this case, there is a question whether "the Western" whom one may regard as secular and alien to Islamic values, meanwhile Islamic fundamentalism and/or radicalism would be Islamic, or on the other hand even it is often conflicted to "the established" Islam in the South-east Asia region.

\section{B. METHODOLOGY}

In this section argued that, in a qualitative study, primary data collection techniques were observation, in-depth interviews, document study, and the three combined or triangulation. It should be noted that the technique of collecting data by observation, it is worth noting what is observed, when interviewed, to whom will conduct the interview (Sugiyono, 2009:147).

Data is the raw material if processed through a series of analyzes can deliver a variety of information (Usman \& Purnomo, 2008:15). The data source of this research is the source of the data needed for the study. According Suharsimi Arikunto (2006:129) "The data source is the subject from which the data can be obtained." Based on the data source can be divided into two, namely primary data and secondary data.

\section{RESULT AND DISCUSSION}

\section{Global Religious and Secular Influences}

\section{a. Religious Fundamentalism}

Islamic fundamentalism also called Jihadism has been a global phenomenon since it becomes so interesting in most governments and security services around the world after the attack on the Pentagon, and most importantly on the Twin Towers of the World Trade Centre of New York in 9 November 2001. This world topic has been spreading in countries where Muslims are in Majority. Subhash Kapila, for example, identifies the emergence of Islamic fundamentalism in South-east Asia. It first appeared in Kelantan, North Malaysia, and Southern Thailand. Recently, he says that the entire Malay Northern States are under the political control of Islamic fundamentalist parties. Clashes with Thai Government forces are reported from Southern Thailand. In Indonesia its appearance has been recent and more pronounced after the fall of the late President Suharto (Subhash Kapila, Accessed on 19 October 2011).

However, the term of fundamentalism among most Islamic writers and intellectuals, along with a number of western scholars are objected. They consider it as either irrelevant to Islam or a dubious concept alien to the cultural heritage of Muslims. In this case, Youssef M. Soueiri promotes alternative terms such as Islamism, political Islam, and Islamic Resurgence (Youssef M. Choueiri, 2010)). In his opinion, "fundamentalism in historical Islam was in its early development associated with a scholarly and religious activity, undertaken for the purpose of elucidating the principles and sources of a particular discipline." However, in modern time, "Islamic fundamentalism combines political action with an ardent desire to discover the original blueprint of a pious community and its ideological principles." 
Nelly Lahoud and Anthony $\mathrm{H}$. Johns write that in general the phenomenon of Islamism emerge after the attacks of World Trade Centre showing Islam become increasingly concerned to establish their presence in the world using Islam as their personal, cultural and political identification, and for some ultimately to deploy Islam as a tool to justify a militant political activism. In this case, Islamism has been represented to the elevation of a commitment to Islam to the level of an ideology, and referred to groups who use Islam as a referent to define their political identities. By defining Islamism like this, however, groups that are included in political parties that profess to be Islamic parties in their political activities are also Islamism. So, for those who see Islam as a universalist ideology on the world stage, likewise regard it as a system to put to rights what they deem as the imbalance and injustice in the world are the extreme manifestation of radical Islamism. This extreme manifestation approaches Islam according to their aspirations and political agendas, and use it as a justification for the use of terror as a political weapon (Nelly Lahoud and Anthony H. Johns, 2005).

This is the reason for Lahoud and Johns become to recognize that Islamism in its manifestation vary and not all Islamists engage in violence. For them committed radical Islamists are fringe groups in the world of Islam; it cannot be overemphasized that far from being a movement that concerns only the West. Islamism as a political current and in all its forms is also recognized as problematic by Muslims in general and cannot boast an acceptance by the mainstream Muslim community. As an example in Indonesia, although Islam has had little influence on politics and society, in wider community most Islamic leaders, such as represented by the two largest Muslim organisations Nadhlatul Ulama (NU) and Muhammadiyah deny adopting fundamentalism (means radical Islamism). They prefer to promote a moderate form of Islam and forge national unity. For them, to develop Islam must be conducted within the corridors of moderation, far from extremism, either (of the political) left or right, and atheism. Such moderation should come along with national movement, as Indonesia is not an Islamic based state.

The process of Islamisation in Indonesia evidently shows on the growing popularity of Islamic attire and devotions, as well as increasing demand both for popular Islamic literature and works of Islamic learning (Fealy). On the other hand, in Malaysia, as revealed by Fealy, Islam has had a bigger impact on society and state than on that of any other Southeast Asian nations. From Malayan independence in 1957, Islam was accorded a privileged position. The Constitution states that 'Islam is the religion of the Federation', though the religious freedom of all citizens is also guaranteed. Meanwhile, islamisation in Malaysian politics and society is apparent in the growing centrality of Islamic symbols and language in political discourse, as well as in the more extensive application of Islamic law.

\section{Global Movement on Gender Equality}

Islamism like any other religious fundamentalisms has increasingly spread may partly be perceived to a threat of an increasingly complex globalised world and to the spread of putatively alien values. It may be aimed at the establishment of a different set of socio-cultural values and socio-political systems (Derichs and Fleschenberg). This may become to affect Mislms' acceptance on gender equality. The increased globalisation of social, political and economic practices, such as the global movement on gender equality in different Muslim countries has led to arise Muslim's consciousness on the equal status of Muslim women prescribed in Islam. However, at the same time it emerge differences among Muslim societies, either of those who endorse and champion the women's cause in the global mindset or those who deny any dichotomy between religious and secular realms. 
Promoted by the United Nations, gender equality has become a worthy goal that lies at the heart of human rights and central to progress in human development. Firstly it was promulgated by Division for the Advancement of Women (DAW) of the United Nations. In 1975 DAW has started to hold the World Conference on the International Women's Year held in Mexico City. Coming along with this, it recommended making state machineries to promote gender equality. Further, support of promoting gender equality is followed by subsequent world conferences on women in 1980 (held in Copenhagen) in 1985 (held in Nairobi) and 1995 (held in Beijing). On December 18, 1979 the United Nations General Assembly adopted the Convention on the Elimination of All Forms of Discrimination against Women (CEDAW) as an international human rights treaty that focuses on women's rights and women's issues worldwide.

Gender equality as governments' policy has been embodied in the 1995 Beijing Platform for Action as identified institutional mechanisms for the advancement of women in the twelve critical areas of concern. These include in the main obstacles to women's advancement: women and poverty, education and training of women, women and health, violence against women, women and armed conflict, women and the economy, women in power and decision-making, institutional mechanisms for the advancement of women, human rights of women, women and the media, women and the environment, and the girl child. These twelve critical areas in which women's status lags behind show the need to remedy women's conditions to meet the requirements of gender equality. With these twelve, the Fourth World Conference on Women produced the message that gender mainstreaming should be a key strategy to reduce inequalities between women and men that should be carried out by all Governments and other actors to promote an active and visible policy of mainstreaming a gender perspective in all policies and programs, so that before decisions are taken, an analysis is made of the effects on women and men respectively (UNESCO 1995, Accessed on 6 Apr 2006).

Gender mainstreaming, one of its components includes women in decision making, was defined by the United Nations Economic and Social Council in 1997 as 'a strategy for making women's as well as men's concerns and experiences an integral dimension of the design, implementation, monitoring and evaluation of the policies and programs in all political, economic and societal spheres so that women and men benefit equally and inequality is not perpetuated anymore. The implementation of gender mainstreaming is measured by its success on the so-called Genderrelated Development Index (GDI) that accounts for the human development impact of existing gender gaps in the three dimensions: life expectancy at birth, adult literacy rate and mean years of schooling, and income as measured by real gross domestic product per capita. Among South-east Asian Nations in 2004 the measurement of GDI has listed Indonesia in rank $90^{\text {th }}$, which means the lowest among 4 South-east Asian countries. Meanwhile, Malaysia is on the 52th, Thailand is on 61th, Philippines is on $66^{\text {th }}$, and Vietnam is on 87th. However, in term of advancing women in decision making bodies, Indonesia would be a bit more advance to others, as explained below.

\section{Muslim Women in Decision Making Bodies}

The movement toward gender equality in formal politics has advanced in the latest form of international convention embodied in The Beijing Declaration and Platform for Action. It was adopted unanimously at the Fourth World Conference on Women (4-15 September 1995) by representatives from 189 countries. The twelve critical areas for women's advancement have strengthened the relationship between these areas and the improving women's political participation in decision making and women's advancement in general. A full involvement of women in decision-making at all levels is intended to play a pivotal role in the general process of the advancement of women. In other words, there is a close reciprocal relationship between the 
general advancement of women, including education and formal economic activity, and the participation of women in decision-making (UN 1992). It is mentioned in the Beijing Declaration and Platform for Action, paragraph 183:

Women's equal participation in decision-making is not only a demand for simple justice or democracy but can also be seen as a necessary condition for women's interests to be taken into account. Without the active participation of women and incorporation of women's perspectives at all levels of decision-making, the goals of equality, development and peace cannot be achieved.

The close relationship between the 12 critical areas and women's advancement in politics has lead to awareness of the lack of women's representation in politics among the champions of gender equality. Although women who constitute half of population in participating election, in their opinion they are not followed success at the following right, i.e. representing women's constituents. Therefore, their endorsement on the Beijing Platform for Action Governments is to encourage (as written in article 7 of the CEDAW) to give women the right to participate in decision making and public policy, and to allow them to exercise that right. These are the basic political rights since it refers to women's rights to vote and to hold office. CEDAW has provided the basis for realizing equality between women and men through ensuring women's equal access to, and equal opportunities in, political and public life, including the right to vote and to stand for election. State parties have to agree to take all appropriate measures, including legislation and temporary special measures, so that women can enjoy all their human rights and fundamental freedoms (ECOSOC, CEDAW, 1979).

A message of CEDAW to ensure women's right has finally promote a temporary special measure on the so-called women's quota. Drude Dahrelup argues that women's quotas are a possible method for achieve a dramatic increase in women's representation (Drude Dahrelup,2002). Women's quotas as an affirmative action tool exist to redress the gender inequality that persists in politics. This also means that women's quotas aim to achieve political equality and are thus applied as a temporary measure. The use of quotas will discontinue when the barriers for women's entry into politics are removed. Women's quotas are aimed to achieve fixed outcomes; when women constitute at least a critical minority of 30 or 40 per cent in politics the quotas should be phased out.

\section{a. Indonesian Case}

In response to the UN's first Conference on Women, Indonesia's government supported the UN women's year in 1975 and the UN decade for women (1975-1984). For the first time, the government established the Junior Ministry of Women's Roles in 1978 with the aim of promoting women's roles in the country's development. In 1983 this junior ministry became the State Ministry for Women's Roles. Early in 1980, the government signed the UN Convention on the Elimination of All Forms of Discrimination against Women (CEDAW) that lays the foundation for women's equal rights. Furthermore, Indonesia's government ratified the CEDAW Convention into Law No. 7 on the Elimination of All Forms of Discrimination against Women enacted in 1984. These endorsements of UN conventions and implementations to improve women's status have been pointed to as a source of the women's movement to demand equal representation in decision making (Nur Iman Subono). Apart from this, the fall of the New Order has brought a new formulation of the 1995 GHBN (Broad Outlines of the State Policy). It clearly identifies, for the first time, gender equality and gender equity as national development objectives. It also re-emphasizes the need to improve the status and role of women in relation to national life, as well as to bring about gender equity and equality in national development (Centre for Population and Policy Study 
Gadjah Mada University \& The Office of the State Ministry of the Women Empowerment, 2002). Various approaches to improve women's lives through national development programs have been accommodated from WID (Women in Development), GAD (Gender and Development) to Gender mainstreaming.

Apart from Indonesia's Government's policies, the increasing global definition of women's issues in the aftermath of the UN's declaration of the International Women's Decade has also strengthened women's voices. New Indonesian women's organizations were also established in the 1980s. Women's organizations, such as Yasanti of Yogyakarta and Kalyanamitra of Jakarta were established to complement the government's funded women's organizations such as PKK and Dharma Wanita whom have been regarded had little awareness on gender issues. They and other mushrooming women's organizations claimed themselves operate their programs independently in helping oppressed people, such as women, labors, farmers, fishermen, those who gained disadvantages as a result of development progress (Ruth Indiah Rahayu, 1996).

Specific to women's advancement in politics Indonesia's Government has enacted the Law No. 12/2003 for the 2004 Election, article (65:1) mentions that all political parties 'may' include a minimum of 30 per cent of women candidates for legislative offices at all levels. Such $30 \%$ quota has been implemented in the 2004 Election which came along with demands of women activists. The result was that 62 women among 550 members of Parliament $(11.3 \%)$ were appointed. Meanwhile, the 1999 Election, the first election at the Reformation era was only promoted 45 women out of 500 members of Parliament (9\%). In the following election, again Indonesia's Government also has published the Act No. 10/2008 on membership of National and Regional Legislative; and the Act No. 2/2008 on Political Parties. Both acts have given mandate to political parties to fulfill $30 \%$ quota of women in politics, especially in legislatives. Women representation in legislatives from time to time has been improving as seen from 1999-2004 (9\%), then 2004-2009 (11.3\%) to 2009-2014 (17.7\%). Moreover, the National Committee of Election 2009-2014 reports that in the DPD (Regional Representative Council, women constitute $22.7 \%$. As an illustration the up and down numbers of women's representation in Indonesia's Parliament (DPR RI), as follows:

\begin{tabular}{|c|c|c|}
\hline Served Period & Women & Men \\
\hline 1950-1955 (Temporary DPR) & $9(3.8 \%)$ & $236(96.2 \%)$ \\
\hline $1955-1960$ & $17(6.3 \%)$ & $272(93.7 \%)$ \\
\hline Constituent Assembly: 1956-1959 & $25(5.1 \%)$ & $488(94.9 \%)$ \\
\hline $1971-1977$ & $36(7.8 \%)$ & $460(92.2 \%)$ \\
\hline $1977-1982$ & $29(6.3 \%)$ & $460(93.7 \%)$ \\
\hline $1982-1987$ & $39(8.5 \%)$ & $460(91.5 \%)$ \\
\hline 1987-1992 & $65(13 \%)$ & $500(87 \%)$ \\
\hline $1992-1997$ & $62(12.5 \%)$ & $500(87.5 \%)$ \\
\hline $1997-1999$ & $54(10.8 \%)$ & $500(89.2 \%)$ \\
\hline 1999-2004 & $46(9 \%)$ & $500(91 \%)$ \\
\hline $2009-2014$ & $17,6 \%$ & $82,4 \%$ \\
\hline
\end{tabular}

Source: DPR Secretariat, 2001. Data formulated by the Division on Women and the Elections, CETRO, 2002.

In global phenomena, quotas as an affirmative action measure have raised resistance, as well Indonesia. Drude Dahrelup enlists arguments of apposing quotas as follows:

1. Quotas are against the principle of equal opportunity for all, since women are given preference.

2. Quotas are undemocratic, because voters should be able to decide who is elected. 
3. Quotas imply that politicians are elected because of their gender, not because of their qualifications and that more qualified candidates are pushed aside.

4. Many women do not want to get elected just because they are women.

5. Introducing quotas creates significant conflicts within the party organization (Drude Dahrelup).

The rejection towards women quotas in Indonesia may best represented in the enactment of the first introduced women's quota that was included in the 2003 Election Act, although the following similar Act published in 2008 had found similar resistance with lesser confrontation due to political atmosphere was more open. Erni Haryanti Kahfi illustrates the journey of women in parliaments who supported an affirmative action measure in the so-called quotas so that they could help to achieve approval of Parliament recommendation was finally embedded in the Election Act article 65 enacted in February 2003. The process of enactment took a long journey; the result was still in a soft measure. The word "may" in the article refers to a soft law as it would not affect penalty for those who breach the law (Erni Haryanti, Kahfi, 2009). The enactment seems to a win-win solution as the fact that the executives represented by the Ministry of Internal Affairs and the 1999 election winning party kept questioning about the political capability of women (KOMPAS, 2003). Such article mentions:

Each participating political party may nominate candidates for national parliament the DPR, the Provincial DPRD and the Regency/City DPRD, for each electoral district, giving consideration to representation of women of at least 30 percent (Indonesian version: Setiap Partai Politik peserta Pemilu dapat mengajukan calon anggota DPR, DPRD Propinsi dan DPRD Kabupaten/kota untuk setiap daerah pemilihan dengan memperhatikan keterwakilan perempuan sekurang-kurangnya 30\% (Undang-Undang nomor 12/2003 tentang Pemilihan Umum pasal).

During the battle of making the quotas included in the Election Act, many women members of Parliaments were either involving in the process or supporting from the outside official meetings, but they definitely endorsed the cause of a women's issue. This situation was in contradictory to those who consider women MPs were tokens of their political parties they represent, and of the Parliament Office they worked in. More importantly they were some Muslim women figures who represented Islamic or devout Muslim based parties. Haryanti Kahfi found a senior Muslim woman MP who had been assumed the Parliament for three election times, she represented a long Islamic party showed her support to have more women in politics saying that:

Until now this (women's participation in formal politics) has been a problem of culture, not a problem of religion. The problem comes from people. People who do not understand this might have such wrong misperceptions. And these wrong misperceptions may still exist. For example, based on religious teaching, people can say, "You live as a wife, so what is the purpose of this life?" The answer is, "Heaven for the afterlife. However, Heaven is not here (in the world of politics)." But, for sure serving the husband and the child in the household will lead to heaven. That statement was spoken previously by a representative of party $X$ in there. There is such a point I have heard. So this discouragement is based on an individual's religious perceptions. However, if I look at the Qur'an, there is a specific verse which mentions that whoever does pious deeds both men and women are both faithful people. Why is this verse not applied here? Because you (a female) if you want to go somewhere (politics) they are not willing to accept (Haryanti Kahfi). 
Another young Muslim woman representing an emerging Islamic party said that she believed that changes in the social and political aspects would affect directly to women's lives. Therefore in her view, Muslim women need to involve more in the world of politics.

....changes in the social and political aspects of the country may actually affect a woman's life, such as the increased price of oil. When fuel prices increase, women should prepare themselves earlier as they need to manage their income accurately in order to fit the timetable of having another income. When the rainy season comes, they should be more aware of the coming flood, while they understand why they are forbidden to dispose of garbage into rivers to help maintain the environment. For her this understanding is a minimum; women need to follow things that are happening in their social environment regardless of how busy they are. It is important to be involved with the environment and to be concerned about the development of the country. If necessary she encouraged women to get involved with politics, to prove that they have a shared concern with the people. Their involvement with politics would work toward the betterment of their society.

The acknowledgement of Muslim women MPs who endorsed the enactment of the affirmative action measure above was a little example among many more devout Muslim women who preferred to agree with the affirmative action measure. It is no wonder if Muslims as Meena Sharify-Funk say, such is quoted by Derichs and Fleschenberg mentioning that addressing the peculiar relationship between religiosity, secularity, tradition and modernity with reference to Muslim communities are floating and overlapping concepts which by no means contradict each other. Muslims in general do not simply live "in" tradition" or "in modernity"; rather, they dwell "in between" these two poles, as well as "in between" their secular and religious ideas (Derichs and Fleschenberg). Thus, it is not surprisingly when the 2003 Election Act applied in the 1999 election resulted $9 \%$ of women in Parliament, in the 2009 election as a result of the enactment of the 2008 Election Act, women number in Parliament increased significantly to become 17,6\%.

\section{b. Malaysian Case}

In Malaysia, endorsement on improving women's participation in politics is similar to the Indonesian case. It importantly endorses the Beijing Declaration and the Platform for Action resulted from the United Nations Fourth World Conference on Women, held in Beijing in September 1995. According to Aminah Ahmad, this country has specifically committed itself to strengthen the implementation of the National Policy on Women in order to: (i) involve more women in decision-making; (ii) safeguard their rights to health, education, and social well-being; (iii) remove legal obstacles and discriminatory practices; and (iv) ensure access to and benefits of development particularly in science and technology (Aminah Ahmad,1998).

The first point of Malaysian Government's commitment on women in decision making is explained by Zarizana Abdul Aziz. She says that the government adopted a policy of $30 \%$ women in decision-making levels in the public sector in August 2004 (Zarizana Abdul Aziz, 2008). Prior to this, the Federal Constitution has acknowledged the rights of Malaysian women as citizens to participate in the political and public life of the nation are recognized and guaranteed. A specific article No. 8(1) states "all persons are equal before the law and entitled to equal protection of the law". To ensure there would be no laws that discriminate women, Article 8(2) has been reviewed and amended by the Parliament in August 2001 to include the word "gender" (Usha Devi Rajaratnam, 2010). 
Furthermore, among Malaysian important figures, gender equity has been actually endorsed to be implemented. Dato' Seri Abdullah Badawi who became Prime Minister approved it by espousing an approach to Islam in October 2003. He focused on 10 fundamental principles, one of which is the protection of the rights of minority groups and women:

"which is authentic and rooted within the tradition, yet human, just and compassionate" and "where women will not feel that statements describing Islam as a religion of justice and mercy in reality only speak to women with exceptions - inadvertently or otherwise... "Women receive a specific mention because I believe that despite the fact that women in many parts of the world

have become more emancipated, women in many Muslim countries continue to be marginalised and discriminated against. I find it most lamentable ... that [women have not] gained the status that they are entitled to, in terms of rights, equality and justice" (Zarizana).

Meanwhile, Retired Chief Judge of Malaya, the Honourable Tan Sri Siti Norma Yaakob, in her opening address delivered at the International Conference on Legislations and Mechanisms to Promote Gender Equality', Kuala Lumpur, 28 August 2006 mentioned: "It is my belief that Islam accords women equal rights with men... like many Muslims, I do not believe that Islam, which abhors injustices, treats women any less than it treats men. Women, like men are vice-regents on earth; equal in the eyes of Allah and it is our collective responsibility to ensure that principles of justice and equality are reflected in our laws".

More precise endorsement to the improvement of women in decision making is raised by Wan Azizah: Malaysia, like any other country, needs to have balanced male/female representation in the public sphere, including politics, so that women can participate in high-level decision-making. Having women at the highest levels of decision making not only means the articulation of issues generally perceived to be women's issues, but ensures that the interests and needs of women, who are half of the population, are given due weight and consideration. Beyond that, the presence of women at these levels will mean that women's perspectives will be easier to hear and more highly valued in national discussions, in the direction of creating a more just, open, fair and equitable society (Wan Azizah, 2002).

However, according to Zarizana gender has not been featured prominently in the political scene of Malaysia, as racial or ethnic politics has been the mainstream of post independence politics. Fifty years after independence, political parties are still divided along racial/ethnic lines and there has hardly been any perceptible shift from racial/ethnic politics. This is the reason why gender discourse has also been complicated by conservative religious interpretations. Coinciding with the rise of religious revivalism globally, Malay-Muslim politics has resulted in a rise in ideological political and legal challenges to the legitimacy of women's claims for equality in the context of Muslim culture and religion (Zarizana, 2010).

As a matter of fact, Malaysian accession to CEDAW on 5 July 1995 by reservations to certain articles, such as Article 2 (f), Article 5 (a), Article 7 (b), Article 9 and Article 16 have been considered showing to its non-conformity with Shariah practiced in Malaysia and the Federal Constitution(United Nations Treaty Collection). Nik Salida Suhaila Nik Saleh presents the original reservations read as follows:

The Government of Malaysia declares that Malaysia's accession is subject to the understanding that the provisions of the Convention do not conflict with the provisions of the Islamic Shariah law and the Federal Constitution of Malaysia. With regards thereto, further, the Government of 
Malaysia does not consider itself bound by the provisions of Articles 2 (f), 5 (a), 7 (b), 9 and 16 of the aforesaid Convention. In relation to Article 11, Malaysia interprets the provisions of this Article as a reference to the prohibition of discrimination on the basis of equality between men and women only' (Declarations, Reservations and Objections to CEDAW, Division for the Advancement of Women) (Nik Salida Suhaila Nik Saleh, 2012).

Reservations are declarations made by State Parties to a treaty, and also mean to not accept certain provisions. Therefore, the non acceptance towards certain articles of the CEDAW has been regarded as discriminating against Muslim women. Regarding this, Nik Saleh figures out that there has been a prevalent avoidance of the term feminism in Malaysia. One of the reasons of Malaysian distancing from feminisms is that feminists' movements in Malaysia did not engage with Islam and Islamic intellectuals regarding women's rights until late 1980s. Feminists' organisations were neither incorporate Islamic paradigm in their early generations. This situation continued until early 1990s when feminists' projects remained unapproachable and untouched by Muslim professionals. For Nik Saleh, Shariah is harmonious, therefore, the allegation that Shariah contradicts with the civil legal system in making women unequal and discriminated is questionable. She argues that according to Islam and CEDAW, gender equality laws might come first as equal treatment of women and men, however, if equal treatment brings unequal results, then the laws should play its role to ensure equal outcomes and remove barriers to advancement of either women or men. Until recently, she observes that the Women, Family and Community Development Ministry, established in January 2001, is still studying the necessity to enact a Gender Equality Act as legal reform proposals.

The alienation of gender equality with its various issues including women in decision making may refer to Azizah's acknowledgement that women in decision-making process is far from being included. Women are under-represented in political institutions, due to numerous challenges confront women entering politics. She identifies women's under-representation is caused by among other things are lack of party support, family support and the "masculine model" of political life. Malaysian society is still male dominated so that men are threatened by the idea of women holding senior posts. As the political sphere is compounded by the high premium placed on political power, this has made some men even less willing to share power with women. The following table illustrates women's representation in Malaysian decision making bodies from time to time (Azizah).

\begin{tabular}{|c|c|c|c|c|c|c|c|c|c|c|c|}
\hline TABLE & 1 & WO & EN & CAI & IDA & ES & IN & ENE & $\mathbf{A L}$ & ELF & TIONS \\
\hline Election Year & 1955 & 1959 & 1964 & 1969 & 1974 & 1978 & 1982 & 1986 & 1990 & 1995 & 1999 \\
\hline $\begin{array}{l}\text { Total } \\
\text { Parliamentary } \\
\text { Seats }\end{array}$ & 52 & 104 & 104 & 144 & 154 & 154 & 154 & 177 & 180 & 192 & 193 \\
\hline Women MPs & 1 & 3 & 3 & 2 & 5 & 7 & 8 & 7 & 11 & 15 & 20 \\
\hline$\%$ & 2.00 & 2.90 & 2.90 & 1.38 & 3.25 & 4.54 & 5.19 & 3.95 & 6.11 & 7.80 & 10.36 \\
\hline
\end{tabular}

Source: Rashila Ramli. 2000. "Political Modernization: Gender Equality in Political Participation?" In Abdul Rahman Embong (ed.), Country, Market and Modernization. Bangi: UKM Press, pp. 198-213

Further, the latest record from Malaysian General Election in 2008, women candidates contested for the total of the 222 parliamentary seats and 405 state seats were 130 contestants out of which fewer than 50 were successful (more or less $8 \%$ women in decision making positions). This is for sure still far from the minimum $30 \%$ target proposed by Women, Family and Community Development Ministry in the 9th Malaysia Plan. This number, however, is still considered an improvement from the total of 80 women candidates that contested in the 2004 General elections 
(Rajaratnam). The persistence of low number of women in decision making is identified that since Independence Malaysia has generally subscribed to ethnic and religion based politics. Thus, a new trend would be increasing rejection towards diversity and secularism in favour of state regulation of behaviour, faith, status and identity, mostly in the name of the religious and ethnic interests of the majority Muslim Malays (Abdul Azis Zarizana, 2008).

\section{CONCLUSION}

Recently Muslims all around the world, including Malaysia and Indonesia, have brought different approaches to respond various global movements. Global movement, such as Islamic fundamentalism gains a little ground among Muslims majority, as evidence shows at a very small number of people who involve with it, as Muslims in majority do not support violent, radical characters of Islamic fundamentalism. Another different Islamic movement, i.e. Islamism shows much ground in South-east Asian Muslim based countries, such as Indonesia and Malaysia. Islamism has been encouraging Muslims to establish themselves to be a pious Muslim community, being implemented religious principles in all aspects of Muslims'life. This kind of Islamism which seems to be more palpable in influencing Muslims' acceptance toward gender equality movement that emerges in the two countries.

Both Indonesia and Malaysia have unanimously adopted gender equality notion, a message of the 1995 International Women Conference embodied in the Beijing Declaration and Platform for action. Coming along with this, both countries have also ratified human (including women) rights symbolized in CEDAW. Indonesia has been earlier to ratify the CEDAW in the Act No. 7/1984, while Malaysia embedded it on 5 July 1995 by Reservations. The results are the two countries implement women's political rights differently, at the same time the supports gain from communities variously. In one hand, Indonesia has gained more supports as the table shows on Women's Representation in Indonesia's Parliament (DPR RI) has been increasing significantly. In another hand, Malaysia has been slowing down, not only in the increased number of women's representation in decision making bodies, but gender discourses provide less interest among Malaysian political actors, scholars and writers.

Finally, Islamism which has been growing significantly in the two countries would increasingly affect to different interpretation on gender equality notion. Muslims' understanding on the Islamic revelation (including the holy Qur'an and The Prophets' Tradition) has brought some Muslims to welcome a measure of diversity, while other Muslims demand uniformity. However, since Southeast Asian Muslims are recognized to more peaceful, tolerant and open-minded, such have been proved by Indonesian and Malaysian endorsements on the two kinds of international gender equality treaties, gender equality agenda would become more palpable and decisive in the near future. Malay Muslims as a part of the world community cannot avoidably be departed from international agenda, but Islamic values would not be wiped out either from every aspects of their life. 


\section{References}

Abdul Aziz, Zarizana. (2008). "Mechanisms to Promote Gender Equality in Malaysia: The Need for Legislation," WLUML DOSSIER.

(2010). "Malaysia - Trajectory towards Secularism or Islamism?" in Claudia Derichs \& Andrea Fleschenberg (Eds.). Religious Fundamentalisms and Their Gendered Impacts in Asia, Berlin: Friedrich-Ebert-Stiftung.

Ahmad, Aminah, (1998). "Women in Malaysia," Country Briefing Paper, Department and Social Development Division (SOCD) of the Asian Development Bank (ADB), Kuala Lumpur.

Azizah, Wan 2002, "Perempuan dalam Politik: Refleksi dari Malaysia," in Julie Ballington \& Azza Karam (Eds.). Perempuan di Parlemen: Bukan Sekedar Jumlah, Stockholm: International IDEA.

Centre for Population and Policy Study Gadjah Mada University \& The Office of the State Ministry of the Women Empowerment 2002, Developing of Management of the State Ministry of the Women Empowerment on Gender Mainstreaming in Development, (Jakarta: Centre for Population and Policy Study GMU, Jogjakarta: with The Office of the State Ministry of the Women Empowerment.

Derichs,Claudia \& Fleschenberg, Andrea, (Eds.) (2010). Religious Fundamentalisms and Their Gendered Impacts in Asia. Berlin: Friedrich-Ebert-Stiftung.

Drude Dahrelup (2002). "Using Quota's to Increase Women's Political Representation," in Julie Ballington \& Azza Karam (Eds.), Perempuan di Parlemen: Bukan Sekedar Jumlah, Stockholm: Stockholm: International IDEA.

(2002). 'Quotas - A Jump to Equality? The Need for International Comparisons of the Use of Electoral Quotas to Obtain Equal Political Citizenship for Women' in Regional Workshop on The Implementation of Quotas: Asian Experiences, Jakarta: International IDEA, Jakarta.

ECOSOC. (1979). Convention on the Elimination of All Forms of Discrimination Against Women (CEDAW), United Nations Division for the Advancement of Women Department of Economic and Social Affairs. URL:http://www.un.org/womenwatch/daw/cedaw/, [Accessed on 6 April 2006].

Fealy, Greg. 2005, "Islamisation and politics in Southeast Asia the contrasting cases of Malaysia and Indonesia," in Nelly Lahoud and Anthony H. Johns (Eds.), Islam in World Politics, New York: Routledge.

Haryanti Kahfi, Ern. (2009). Equal Representation of Women in Parliament: Equality, Representation of Women, Parliament, Indonesia's Democratic Transition. Saarbrücken, Germany: VDM Verlag Dr. Müller.

Kapila, Subhash. (2000) "Emergence of Islamic Fundamentalism in South East Asia," Institute of Peace and Conflict Studies, South East Asia Articles \#390 (22 July), $\mathrm{http}: / / w w w . i p c s . o r g / a r t i c l e / s o u t h e a s t-a s i a / e m e r g e n c e-o f-i s l a m i c-f u n d a m e n t a l i s m$ (Accessed on 19 October 2011). 
Nelly Lahoud and Anthony H. Johns (Edits.) (2005). Islam in World Politics, New York: Routledge.

Rahayu, Ruth Indiah. (1996). "Politik Gender Orde Baru: Tinjauan Organisasi Perempuan Sejak 1980-an," Prisma, Majalah Kajian Ekonomi dan Sosial.

Rajaratnam, Usha Devi. (2010). "Representation of Malaysian Women in Politics Language," in India www.languageinindia.com.

Subono, Nur Iman. (2003). Perempuan dan Parisipasi Politik: Panduan Untuk Jurnalis, Jakarta:.Yayasan Jurnal Perempuan (YJP) dan The Japan Foundation.

UN. (1992). Women in Politics and Decision-Making in the Late Twentieth Century, United Nation Office, Dordrecht, Boston, London: Martinus Nijhoff Publishers.

UNESCO. (1995). Gender Equality and Equity, A summary review of United Nations Educational, Scientific and Cultural Organization (UNESCO)'s accomplishments since the Fourth World Conference on Women, Unit for the Promotion of the Status of Women and Gender Equality, URL:http://unesdoc.unesco.org/images/ 0012/001211/121145e.pdf, [Accessed on 6 Apr 2006]

Youssef M. Choueiri. (2010). Islamic Fundamentalism the Story of Islamic Movement, Third Edition, New York: Continuum International Publishing Group. 